\title{
The Araras Escarpment in the upper Paraná River: implications to fluvial neotectonics on the Paraná drainage net evolution
} \author{
Alexandre J. Perinotto ${ }^{1-2}$ \\ ${ }^{1}$ Universidade Guarulhos (UnG) - fulfaro@rc.unesp.br \\ ${ }^{2}$ Universidade Estadual Paulista (Unesp)
}

Vicente José Fulfaro ${ }^{1-2}$, Mario Lincoln Etchebehere ${ }^{1}$, Antonio Roberto Saad ${ }^{1-2}$ ， José

\begin{abstract}
The Paraná River hydrographical basin, the second largest in South America, has in its upper reach an anomalous geomorphological structure, in relation to the general NNE-WSW channel direction. This anomaly occurs south adjacent to the Rio do Peixe river mouth, where the Paraná River makes a U turn controlled by an unique antithetic fault block dipping W. This alteration occurs against the general pattern of the synthetic fault blocks dipping E of its left margin. This anomalous pattern is in accordance to the presence of a NW-SE shear megazone ruled by the Guapiara lineament. Geomorphological data and location of some clay deposits within this region indicate a previous and more ancient channel for this river according with the general NNE-WSW direction of the Três Lagoas Crustal Suture Zone. This new U pattern was formed only after the occurrence of a neotectonic reactivation at the crossing point among the Guapiara Lineament and the Três Lagoas Suture Zone. It is here assumed that the lineament mode $\mathrm{N} 350^{\circ}$ appears as the most probable hydraulic tensor of this region and represents the distensional direction. The lineament swarming $\mathrm{N} 315^{\circ}$ and $\mathrm{N} 40^{\circ}$, as well as those grouped together in mode $\mathrm{N} 115^{\circ}$, may favor transcurrent dextral movements for the NW quadrant and sinistral for the other two directions with transtensive and transpressive deformation. Both are dependent on the local geometry of fracture plains and local stress fields. The most ancient geochronological data obtained until now for seismic liquefaction structure samples from the Rio do Peixe valley, suggest a date of $34 \mathrm{ka} \mathrm{BP}$, indicating that this tectonic regime was still active at this time.
\end{abstract}

Keywords: Araras escarpment Upper Paraná River Basin Neotectonics Fluvial morphology

\section{Resumo}

A bacia do rio Paraná tem em seu trecho superior uma estrutura geomorfológica anômala orientada na direção geral do canal NNE-WSW. Essa anomalia, que ocorre ao sul da foz do rio do Peixe, impõe ao rio Paraná uma trajetória em "U" controlada por uma única falha atitética que mergulha para W. Essa alteração ocorre contra o padrão geral do sistema de blocos de falhas sintéticas que mergulham para E. A anomalia concorda com a presença de o lineamento de Guapiara, uma megazona de cizalhamento de direção NW-SE. Dados geomorfológicos e a posição de depósitos argilosos nessa área indicam um paleocanal do rio Paraná na direção NNE-WSW, de acordo com a zona de sutura crustal de Três Lagoas. O novo padrão "U" foi formado apenas após a ocorrência de uma reativação neotectônica no cruzamento do lineamento de Guapiara e a zona de sutura crustal de Três Lagoas. Assume-se que o lineamento $\mathrm{N} 350^{\circ}$ aparece como o mais provável tensor hidráulico dessa região e representa direções distensivas. $\mathrm{O}$ enxame de lineamentos $\mathrm{N} 315^{\circ}$ e $\mathrm{N} 40^{\circ}$, bem como os de direção $\mathrm{N} 115^{\circ}$, podem ter favorecido movimentos transcorrentes dextrógiros para o quadrante NW e sinistrógiros para as outras duas direções, com deformações transtensivas e transpressivas. Ambos são dependentes da geometria dos planos de fratura e do campo de esforços locais. A idade mais antiga obtida até o momento para amostras provindas de estruturas de liquefação do vale do rio do Peixe é de $34 \mathrm{ka} \mathrm{BP}$, indicando que esse regime tectônico estava ainda ativo a esse tempo.

Palavras chaves: Paredão das Araras, Alto curso do Rio Paraná, Neotectonica, Morfologia fluvial. 


\section{1-Introduction}

The Paraná river hydrographical basin, the second largest drainage net area of South America, occurs in five different countries and occupies an area of 8,6 millions of square kilometers (including the Paraguay river). Of that total $45.6 \%$ lies in Brazil, $29.7 \%$ in Argentina, $13.2 \%$ in Paraguay, $6.6 \%$ in Bolivia and $4.8 \%$ in Uruguay. The Paraná river main drainage channel, formed by the confluence (Brazil, latitude 20oS) of Paranaíba and Grande rivers (Fig. 1), runs roughfly south as far the Rio de la Plata Estuary (Argentina, latitude 34oS). From its divide in the Brazilian Highlands to the mouth near the Juncal Island in the Rio de la Plata Estuary, the Paraná river attains $3,965 \mathrm{~km}$ in length (Orfeo \& Stevaux, 2002). In the Brazilian territory, the Paraná river has $813 \mathrm{~km}$ in length.

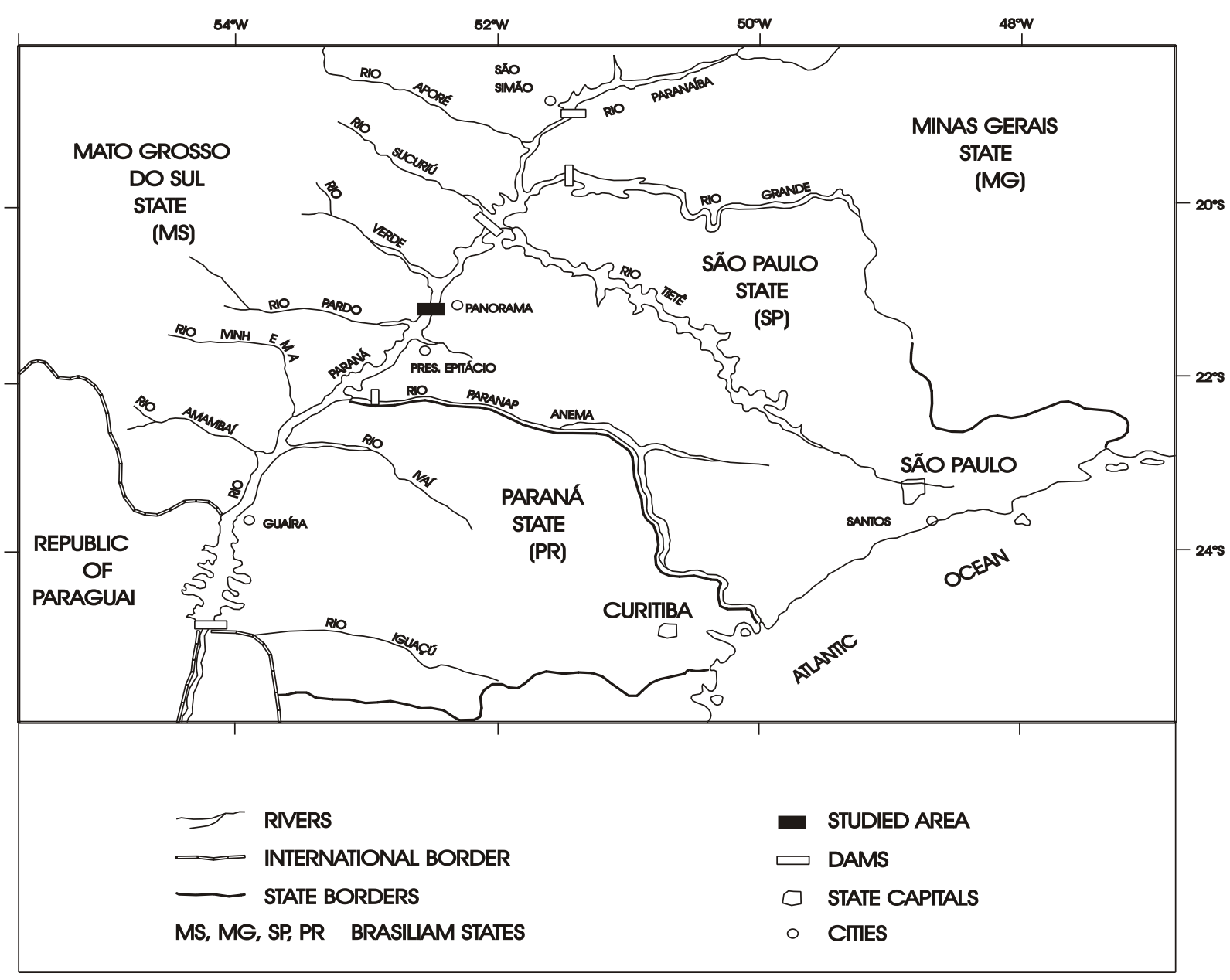

Figure 1- Geographical location of the upper Paraná river.

The upper Paraná river, herein considered, encompasses the section between the Guaira city and the confluence of the Paranaíba and Grande rivers (Nakasu, 1998), figure 1 . In the this study area here described, the Paraná river marks the border of the São Paulo and Mato Grosso do Sul States at approximately $21^{\circ} 30^{\prime} \mathrm{S}$ and $52^{\circ} 00^{\prime} \mathrm{WGr}$, a geographical point in a location named Araras Escarpment ("Paredão das Araras"). Presently, this section of the river is partially drowned by the artificial lake of the Porto Primavera hydroelectrical dam.

\section{Geological and Geomorphological Setting}

The area drained by the upper Paraná river valley in the studied location is mainly constituted by Lower Cretaceous sandstones of the Rio Paraná Formation of the Caiuá Group and locally by the basaltic rocks of the Serra Geral Formation. These basaltic floods reach a minimum thickness of 1,700 meters in this area and have an age of $132.4+/-1$ m.y. (Renne et al.,1995). All of this volcanic extrusion is considered to have occurred within a one million years interval, ranging from the Upper Jurassic to the Lower Cretaceous.

The regionally post-basaltic sedimentary cover is associated to the genesis and evolution of two different basins, named Caiuá and Bauru. Within the studied area the sediments deposits of the Caiuá basin predominate. The Caiuá Group (same name as the homonimous basin) is composed by three units named, from bottom to the top, as Goio-Erê, Rio Paraná and Santo 
Anastácio formations (Fernandes \& Coimbra, 1994). The latter was considered to be a geosoil developed over the two previous units and marked by a strong lateritic pedogenetic process (Fulfaro et al, 1999a). The age group, according to this author, is considered Lower Cretaceous (Aptian/Albian) in age. Sediments of the Bauru group, Upper Cretaceous in age (Dias Brito et al.,1998; Gobbo Rodrigues Et Al., 1998; And Simone \& Mezzalira, 1997) do not occur in the studied area.

In this studied area, the Paraná river posseses an anomalous geomorphological structure characterized by a sudden $U$ turn (Fig. 2) of its course, approximately at $21^{\circ} 30^{\prime} \mathrm{S}$ and $52^{\circ} 00^{\prime} \mathrm{WGr}$, at the limit of the São Paulo and Mato Grosso do Sul states. The São Paulo state margin is constituted by scarps in a sinthetic block faulted system on aeolian sandstones of the Rio Paraná Formation (Caiuá Group). By contrast, the Mato Grosso do Sul margin is represented by a large flood plain, with the exception of the Araras Escarpment, where the Paraná River suddenly shifts from a generally NNEWSW course to an U turn adjacent to the Rio do Peixe mouth.

Nakasu (1998) described three main geomorphological features in the area shown in Figure 2. They are represented by a flood plain and, in an altimetric classification, by a lower, intermediate and upper terraces. The lower terrace (240 to 265 meters) is still subject to exceptional floods having a depositional architecture of ancient channels, bars and natural levees, representing a transition to the present flood plain environment. It is predominant in the Mato Grosso do Sul State margin. The intermediate terrace ( 265 to 280 meters) has a farther location in relation to the present river channel and represents ancient channels not exposed to the present flood regime.

The lower and the intermediate are the most representative terraces in the vicinity of the Rio do Peixe river mouth in the São Paulo state margin, as shown on Figure 2. The upper terrace (290 to 310 meters), the most ancient terrace level, occurs mainly in localized points in the Mato Grosso do Sul State. One of such points is the Araras Escarpment

\section{Evolution And Neotectonics Features Of The Upper Paraná River}

The Paraná river genesis is associated to the denudation of the South American Surface at the end of the Miocene resulting in the formation of the Paraná/Paraguay drainage net (Stevaux, 1996). The South American Surface, as defined by King (1956), was carved during the Paleogene. In the centralwestern region of the São Paulo State its remains characterize watersheds higher than the present system of valleys and associated plains. This pattern is represented by E-W flowing rivers such as the Grande, Tietê, Peixe and Paranapanema (Landim et al., 1974). This present study suggests that these E-W flowing rivers have a strong structural control of WNW-ESSE and E-W lineaments. Most of the gravel deposits covering the upper terraces are appointed as a result of this evolutionary stage (Jabur, 1992; Stevaux, 1993; Souza Filho, 1993; And Santos, 1997).

The Rio do Peixe river (Fig.S 1,2,3A,3B and 4) has its stream course controlled by the Guapiara Lineament. Etchebehere (2000), studying the Rio do Peixe valley terraces, concluded that these deposits were formed in a braided fluvial environment with a minimum age of $34 \mathrm{ka} \mathrm{BP}$, until the limit of the Pleistocene/Holocene. The terrace development was conditioned by tectonic base levels created by a general dextral transcurrent movement, as shown by E-W lineaments probably related to the South American plate rotation to the west, during the Paleogene. The tectonic regional pattern that had be in action during the Late Quaternary, shows a high frequency of E-W, NWSE (290-320 ), N-S (350-10 $)$ and ENE-WSW (50$\left.70^{\circ}\right)$ lineaments. The N-S $\left(350^{\circ}\right)$ lineaments predominate in this region and can be interpreted as an index of hydraulic tension.

The influence of neotectonics processes in the hydraulics of the Rio do Peixe basin is corroborated by the seismic history of this region, named the Presidente Prudente Seismogenic Zone by Mioto (1993), and also by the liquefactions structures described by Etchebehere (2000), which indicate a seismic scenario with magnitude higher than 5.5 points in the Richter scale. It is worth mentioning that the city of Presidente Epitácio (Fig. 2), experienced a natural seismic event in 1922, causing great alarm within its then small population. Previously Suarez (1973) mentioned that the Paraná river thalweg shows evidence of recent changes, specifically between the cities Panorama and Presidente Epitácio (Fig. 2) without stating the source for them. It is exactly at this point of the Parana River that occurs the Araras Escarpment.

The discussion of climate versus tectonic influence in the evolution of the Paraná drainage net occupies the literature for a long time. According to some authors active tectonism never occurred in this area. The reason for that is based on a great misunderstanding of the preponderant action of the current climatic conditions on the nature of the sedimentary deposits but never on the appearance of rivers and their drainage nets. In the present day, with the development of neotectonic studies, we are now able to correlate climate and tectonics to all riverine evolutionary stages peacefully.

\section{The Araras Escarpment}

The $\mathrm{U}$ turn of the Paraná river shown in figure 2 demonstrates the importance of neotectonic movements in the origin of this 
anomalous structure. Its ancient stream course with a straight NNE-WSW direction along the Três Lagoas Crustal Suture Zone course, near the Rio do Peixe mouth (Fig. $3 \mathrm{~A}$ ), is responsable for great depositon of special clays observed at the the Campinal district of Presidente Epitácio. Following an episode of Late Quaternary reactivation along the NW-SE
Guapiara Lineament, at its the crossing point with the Três Lagoas Suture Zone (Fig. 2), this region of normal synthetic fault blocks developed an antythetic faults. This process resulted in the Araras Escarpment and caused disarray in the Rio do Peixe mouth area, where this suddenly dammed river developed a new flood plain containing ponds (Fig. 3B and 4).

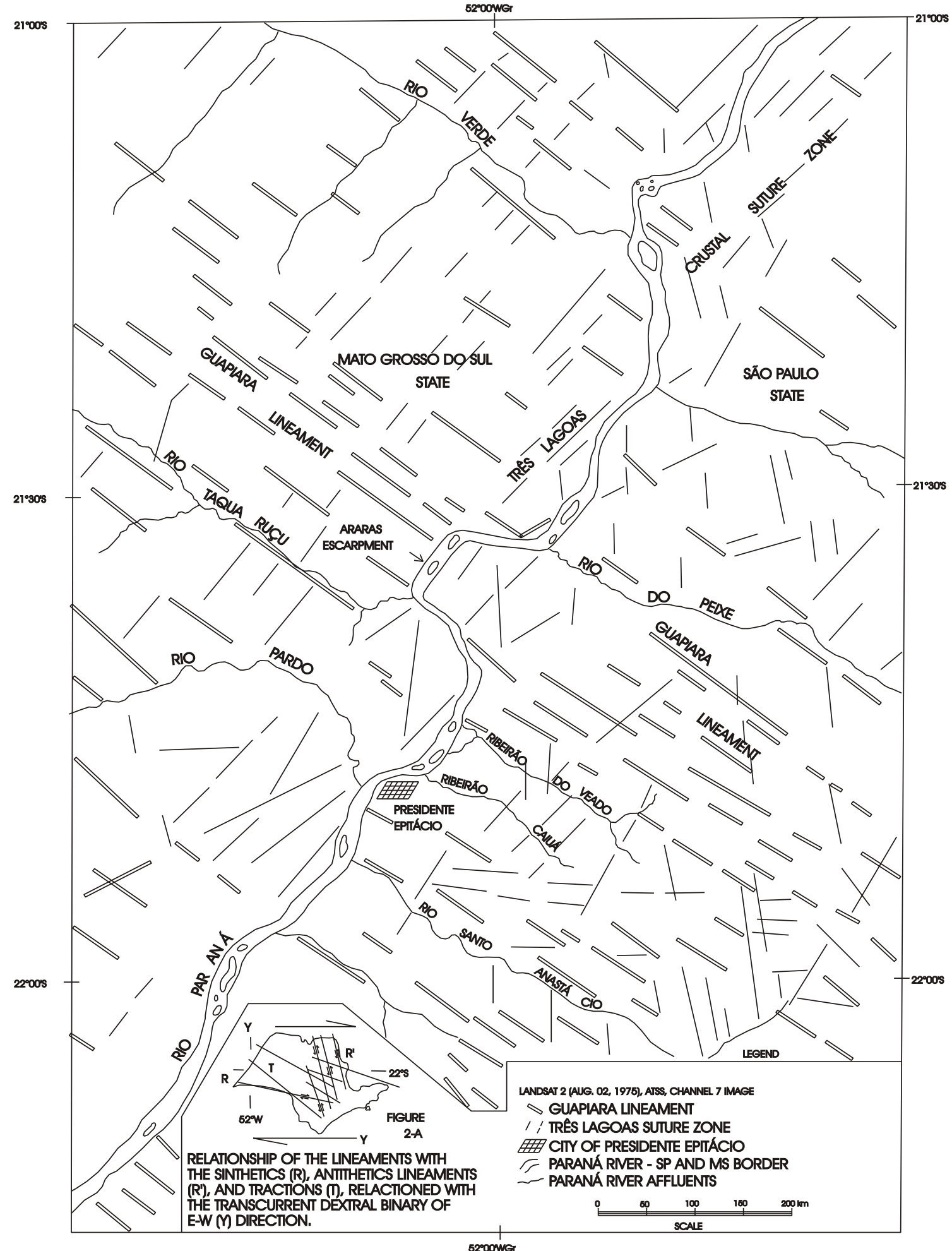

Figure 2- Fotolineaments interpreted from 


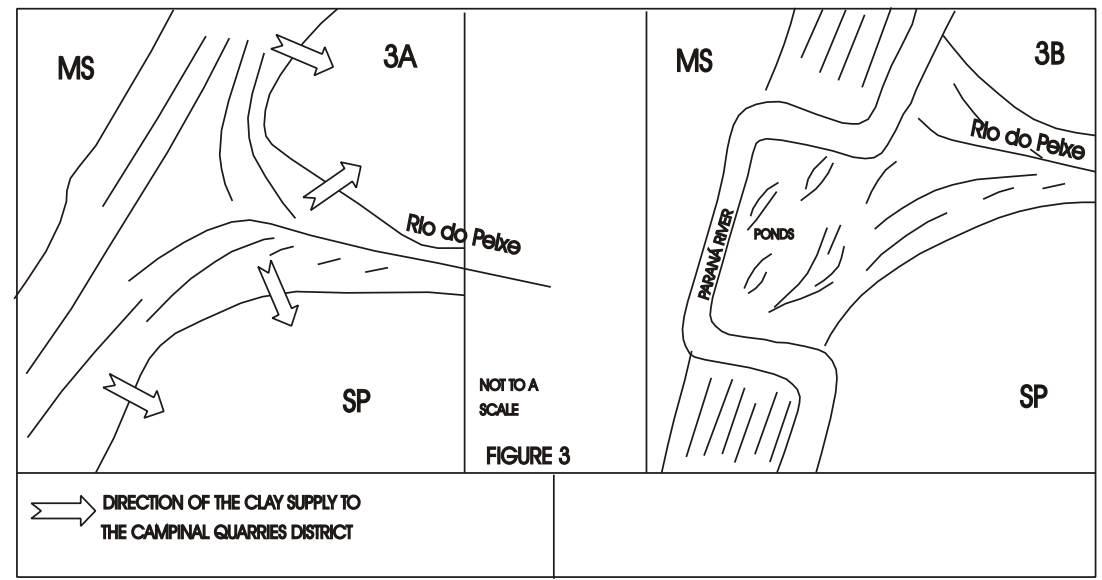

Figura 3a- Paraná river paleodrainage before the stablishement of the araras escarpment.

Figura 3b- Present day Paraná river drainage after the stablishement of the Araras Escarpment, at the ancient rio do peixe mouth several ponds appear.

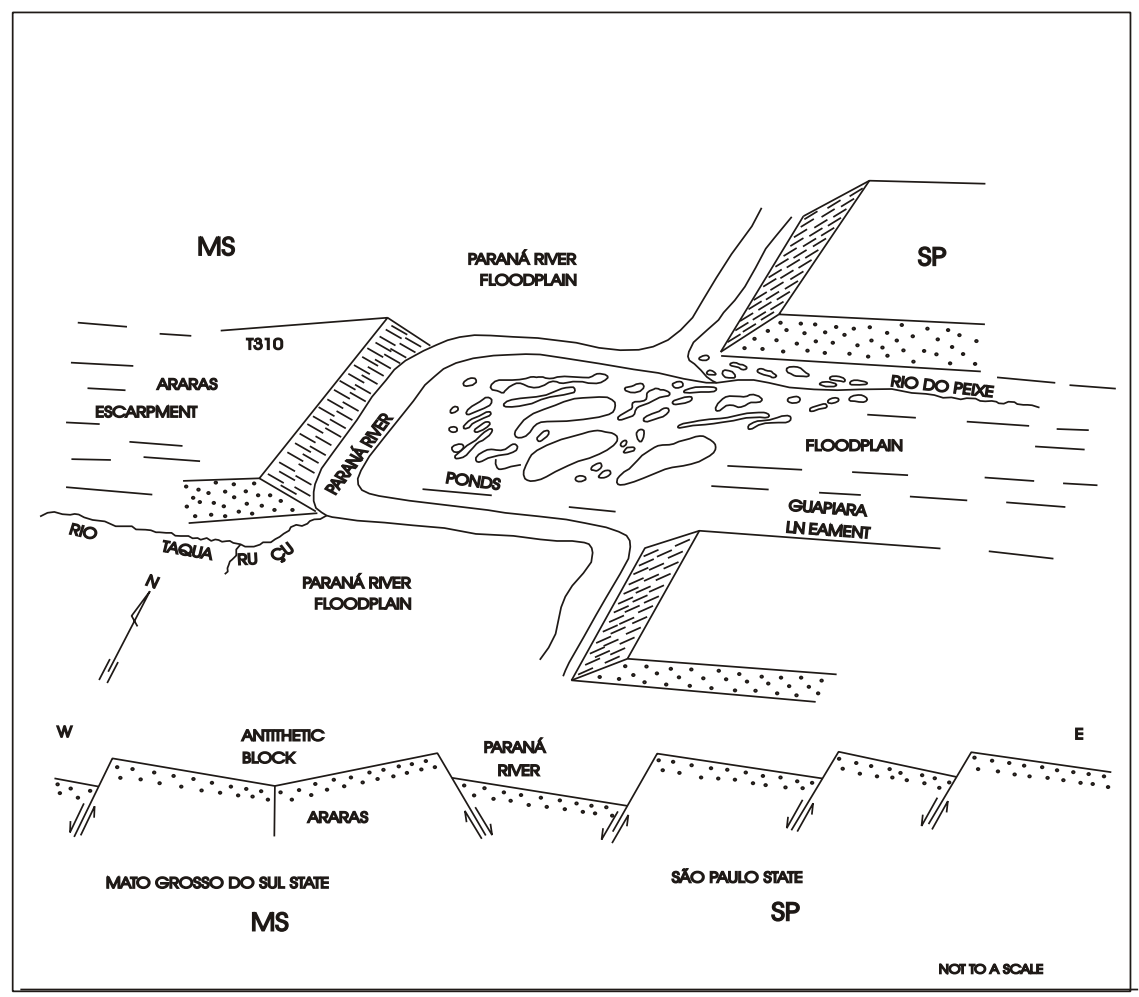

Figure4-HypotheticalmodelforthegenesisoftheAraraescarpmentasanantitheticfaultblockintheMSstateduetoa dextralmovimentation of The Guapiaralineamentinneogenic time. The suddendumpoftheancientrio do Peixemouthleadstotheappearanceodseveralponds. 
As described by Etchebehere et al., in this volume, neotectonics activities in the Western São Paulo State have been observed by several authors (Magalhães Et Al. 1996; Nakasau 1988; Magalhães 1999; Stein 1999; Etchebehere et al. 1999; Etchebehere \& Saad 1999, 2002). Kinematics studies in specific or regional areas and paleoseismics approaches have also been conducted. The kinematics data available in the geologic literature about the Western São Paulo State (Hasui 1990, IPT 1992; Magalhães et al. op. cit.; Riccomini 1997; Hasui et al. 1999; Magalhães op. cit.) point out to the action of dextral slip transcurrent fault movement in a large EW lineament swarms. This would reflect in a pattern of interior tectonic movements, possibly connected to a westward displacement of the South American tectonic plate. In areas between two lineament swarms, as it is the case of the Rio do Peixe valley, the ellipsoid stress had its maximum axis oriented to a NW-SE direction, thus influencing the appearance of transpressive and transtensional structures. The latter, by its turn, ended up controlling both the fluvial dynamics as well as the formation and preservation - or destruction - of alluvial deposits. Meanwhile, data obtained from the Brasilia, Rio del Plata, and Fortaleza GPS (Global Positioning System) monitoring stations allowed the positioning of tectonic plaques with millimetric precision for latitude, longitude and altitude changes. These data show a persistent NNW drift of the South American plate, with a rate of about $2 \mathrm{~cm} /$ year (Heflin and others, 2003, apud Caltech). Based on systematic studies of lineaments taken from satellite images, Corsi et al. (2003) determined the major lineament swarms drawing the attention to the modes $\mathrm{N} 280^{\circ}, \mathrm{N} 315^{\circ}, \mathrm{N} 350^{\circ}$, $\mathrm{N} 15^{\circ}, \mathrm{N} 40^{\circ}$, and $\mathrm{N} 80^{\circ}$. Putting this geometric picture together with the information given by the GPS system, we believe that the N350 lineament mode is the most probable hydraulic tensor for the Planalto Ocidental Paulista, because it represents the distensional direction. The $\mathrm{N} 315^{\circ}$ and $\mathrm{N} 40^{\circ}$ lineaments, as well as those grouped together in mode $\mathrm{N} 115^{\circ}$ may favor transcurrent movements: dextral for the NW quadrant and sinistral for the other two directions with transtensive and transpressive deformations, that are dependent on the local geometry of the fracture plains and local stress fields. This Late Quaternary tectonics event is here considered responsible for the Araras escarpment formation. However, the exact dating of the beginning of its current stress can not yet be exactly determined.

The hypothesis of a combined action of climatic and neotectonic factors in the Paraná River was already mentioned by Iriondo (1988), Stevaux (1993) And Souza Filho (1993), based on small faults in gravel deposits and on the Paraná channel assimetry and its sedimentary wedge. The sedimentary deposits in the Paraná valley present a strong assimetry, ranging from 5 to 6 meters in thickness in the flood plain to 10 to 15 meters in the main channel (Stevaux et al. 1997).

\section{Acknowledgment}

The authors wish to acknowledge Dr. Paulo Eduardo de Oliveira for the kind review of the English version of the manuscript.

\section{Bibliography}

\section{CALTECH - CALIFORNIA INSTITUTE OF} TECHNOLOGY. 2004. GPS Time Series. Jet Propulsion Laboratory. http://sideshow.jpl.nasa.gov/mbh/series .html. Accessed in 13.03.04.

Corsi, A. C., Etchebehere, M. L. C., Saad, A. R., Perinotto, J.A. J., Fulfaro, V. J., Morales, N. 2003. Avaliação do arcabouço estrutural do Planalto Ocidental Paulista mediante análises de lineamento. In: Encontro de Pesquisa UnG - 2003, 2003, Guarulhos/SP.

Dias Brito, D.; Muzachio, E.A.; Maranhão, M.A.S.; Castro, J.C.; Suarez, J.M.; Rodrigues, R. 1998. Cretaceous nonmarine calcareous microfossils from the Adamantina Formation (Bauru Group), Western São Paulo State, Brazil. In: Annual Conference Of The South Atlantic Mesozoic Correlation Projet 381-3, Comodoro Rivadavia, Argentina, 1998. Abstracts... Comodoro Rivadavia, IGCP-IUGS, Boletim 2 (Edición Especial), Ano I: 8-10.

Etchebehere, M.L.C. 2000. Terraços neoquaternários no vale do Rio do Peixe, Planalto Ocidental Paulista: implicações estratigráficas e tectônicas. Rio Claro. 2v. (Ph.D. Thesis, Instituto de Geociências e Ciências Exatas da Universidade Estadual Paulista UNESP).

Etchebehere, M.L.C. \& Saad, A.R. 1999. Relação Declividade / Extensão de Curso (RDE) aplicada à detecção de deformações neotectônicas regionais na bacia hidrográfica do Rio do Peixe, SP. In: Simpósio De Geologia Do Sudeste, 6, São Pedro, 1999. Abstracts... Rio Claro, SBG-SP/RJ-ES/UNESP, p. 93.

Etchebehere, M.L.C. \& Saad, A.R. 2002. Feições de liqüefação em sedimentos quaternários no vale do Rio do Peixe, região ocidental paulista - Implicações paleossísmicas. Geociências, v. 21( 12): 43-56.

Etchebehere, M.L.C.; Saad, A.R.; Fulfaro, V.J. 1999. Neotectônica no vale do Rio do Peixe, SP Evidências de liqüefação em sedimentos cenozóicos. In: Simpósio de Geologia do Sudeste, 6, São Pedro, 
1999. Abstracts.. Rio Claro, SBG-SP;RJES/UNESP, p. 94.

Etchebehere, M.L.C.; Saad, A.R.; Fulfaro, V.J.; Perinotto, J.A.J. In press. Aplicação do Índice "Relação Declividade-Extensão RDE" na Bacia do Rio do Peixe (SP) para detecção de deformações neotectônicas. Revista Geologia USP.

Etchebehere, M.L.C.; Saad, A.R.; Fulfaro, V.J.; Perinotto, J.A.J. In this volume. Detection of neotectonic deformations in the Rio do Peixe valley, western São Paulo State, Brazil, based on the distribution of Late Quaternary allounits. Rev. Bras. Geomorfologia (in press).

Fernandes, L.A. \& Coimbra, A.M. 1994. O Grupo Caiuá $(\mathrm{Ks})$ : revisão estratigráfica e contexto deposicional. Rer. Bras. Geoc., V.24(3): 164-176.

Fulfaro, V.J.; Etchebehere, M.L.C.; Perinotto, J.A.J.; Saad, A.R. 1999 a. Santo Anastácio: um geossolo cretácico na Bacia Caiuá. In: Simpósio Sobre O Cretáceo do Brasil, 5, Serra Negra (SP), 1999. Boletim... Serra Negra, UNESP, p.125-130.

Fulfaro, V.J.; Etchebehere, M.L.C.; Perinotto, J.A.J.; Saad, A.R. 1999 b. Bacia Caiuá: uma nova bacia cretácica na Bacia do Paraná. In: Simpósio Sobre O Cretáceo Do Brasil, 5, Serra Negra (SP), 1999. Boletim... Serra Negra, UNESP, p.439-442.

Gobbo Rodrigues, S.R.; Petri, S.; Bertini, R.J. 1998. Possibilities of biotic correlation between Bauru Group (Paraná basin, Brazil) and Neuquén Basin (Argentina) in the Upper Cretaceous. In: Annual Conference Of The South Atlantic Mesozoic Correlation Projet 381-3, Comodoro Rivadavia, Argentina, 1998. Abstracts... Comodoro Rivadavia, IGCP-IUGS, Boletim 2 (Edición Especial), Ano I:. 15-16.

Hasui, Y. 1990. Neotectônica e aspectos fundamentais da tectônica ressurgente no Brasil. In: Workshop sobre Neotectônica e Sedimentação Cenozóica Continental No Sudeste Brasileiro, 1, Belo Horizonte. Proceedings... Belo Horizonte, SBG-MG: 1-31.

Hasui, Y. \& Sena Costa, J.B. 1996. Neotectônica Fundamentos, métodos e técnicas de análise. In: Simpósio de Geologia da Amazônia, 5, Belém, 1996. Course Notes... Belém, SGB-Núcleo Norte, 20 p.

Hasui, Y.; Sena Costa, J.B.; Borges, M.S.; JimenezRueda, J.R.; Morales, N. 1999. Compartimentação neotectônica do lineamento Paranapanema. In: Simpósio Nacional de Estudos Tectônicos -SNET, 7, Lençóis, BA, 1999. Proceedings... Lençóis, SBG-BA, Sessão 4: 37-39.

IPT - INSTITUTO DE PESQUISAS TECNOLÓGICAS DO ESTADO DE SÃO
PAULO S.A. 1992. Sismotectônica e dinâmica superficial na área do Complexo Hidrelétrico Canoas. São Paulo. 4v. (IPT, Relatório 30.924).

Iriondo, M.H. 1988. A comparison between the Amazon and Paraná Rivers Systems. Mittcilung der GeologischPaleontologisches. University of Hamburg (pre-print).

Jabur, I.C. 1992. Análise paleoambiental do Quaternário superior na bacia hidrográfica do Alto Paraná. Rio Claro. (Tese de Doutoramento, IGCE- Instituto de Geociências UNESP)., $184 \mathrm{p}$

King, L.C. 1956. A geomorfologia do Brasil oriental. Rev. Bras. Geogr., v.18(2):147265.

Magalhães, F.S. 1999. Tensões regionais e locais: casos no território brasileiro e padrão geral. São Carlos. (Ph.D., Escola de Engenharia de São Carlos - Universidade de São Paulo - USP). 225 p.

Magalhães, F.S.; Etchebehere, M.L.C.; Saad, A.R.; Fulfaro, V.J. 1996. Análise estrutural do Grupo Bauru na região do alto Rio do Peixe, Estado de São Paulo. In: Simpósio Sobre O Cretáceo Do Brasil, 4, Rio Claro. Proceedings... Rio Claro, 1996, UNESP, p.: 283-287.

Mioto, J.A. 1993. Sismicidade e zonas sismogênicas do Brasil. Rio Claro, 2v. (Tese de Doutoramento, IGCE Instituto de Geociências-UNESP).

Nakasu, L. 1998. Recursos minerais do rio Paraná a montante de Guaíra. Rio Claro. (Tese de Doutoramento, IGCE-UNESP). $212 \mathrm{p}$

Orfeo, O. \& Stevaux, J.C. 2002. Hydraulic and morphological characteristics of Middle and Upper reaches of the Paraná river (Argentina and Brazil). Geomorphology, 44:309-322.

Popolizio, E. 1982. Geomorphology of the Argentina Northeast. Water International, 7:162-177.

Renne, P.R.; Ernesto, M.; Pacca, I.G.; Coe, R.G.; Glen, J.M.; Prevot, M.I.; Perrin, M. 1992. The age of the Paraná flood volcanism, rifting of Gondwanaland, and the Jurassic-Cretaceous boundary. Science, 258:.975-979.

Riccomini, C. 1997. Arcabouço estrutural e aspectos do tectonismo gerador e deformador da Bacia Bauru no Estado de São Paulo. Rev. Bras. Geoc., v. 27, n. 2, p.: 153-162.

Santos, L. 1997. Estratigrafia e evolução do sistema siliciclástico do rio Paraná no seu curso superior: ênfase à arquitetura dos depósitos, variação longitudinal das fácies e processos sedimentares. Porto Alegre, 2v. (Phd Thesis, Universidade Federal do Rio Grande do Sul UFRGS). 
Fulfaro, V.J. et. al./ Revista Brasileira de Geomorfologia, Ano 6, № 1 (2005) 115-122

Simone, L.R.L. \& Mezzalira, S. 1997. A posição sistemática de alguns bivalves uniomoidea do Grupo Bauru (Cretáceo superior) do Brasil. Revista UnG-Geociências, 2(6):6365.

Souza Filho, E.E. 1993. Aspectos da geologia e estratigrafia dos depósitos sedimentares do rio Paraná entre Porto Primavera (MS) e Guaira (PR). São Paulo. (Phd. Thesis, Instituto de Geociências da Universidade de São Paulo). $214 \mathrm{p}$

Stein, D.P. 1999. Avaliação da degradação do meio físico - Bacia do rio Santo Anastácio, Oeste Paulista. Rio Claro. (Ph.D. Instituto de Geociências e Ciências Exatas da Universidade Estadual Paulista - UNESP).

Stevaux, J.C. 1993. O rio Paraná: geomorfogênese, sedimentação e evolução quaternária do seu curso superior (região de Porto Rico, PR). São Paulo. (Tese de Doutoramento, Instituto de Geociências da Universidade de São Paulo). 243 p.

Stevaux, J.C.; Souza Filho, E.E.; Jabur, I.C.; 1997. A história do rio Paraná em seu alto curso. In: Vazzoler, A.E.A.N.; Agostinho, A.A.; Hahn, M.S. (eds.) A planície de inundação do Alto Rio Paraná. EDUEM-UEMNUPÉLIA, Maringá, Brasil, p.47-72.

Suarez, J.M. 1973. Contribuição à geologia do extremo oeste do Estado de São Paulo. Rio de Janeiro. Bol. Geogr., 2-34( 248):.119155. 